\title{
PERHITUNGAN ESTIMASI WAKTU PADA PRODUKSI BARANG DENGAN MENERAPKAN ALGORITMA NAIVE BAYES KLASIFKASI (STUDI KASUS PT. HASIL RAYA INDUSTRIES)
}

\author{
Rima Rizqi Wijayanti ${ }^{1}$, Abdurrasyid \\ ${ }^{1}$ Program Studi Informatika, Fakultas Teknik, Universitas Muhammadiyah Tangerang Jalan Perintis \\ Kemerdekaan 1/33 Cikokol Kota Tangerang \\ ${ }^{2}$ Program Studi Informatika, Fakultas Telematika Energi, Institut Teknologi PLN Jalan Lingkar Luar \\ Barat, Cengkareng, Jakarta Barat \\ Co Responden Email : rimarizqi@ft-umt.ac.id
}

Article history

Received Nov 17, 2020

Revised Jan 15, 2021

Accepted Jan 30, 2021

Available online Feb 28 , 2021

\section{Keywords}

Estimated, Production, Naive Bayes Classifier
Riwayat

Diterima 17 Nov 2020

Revisi 15 Jan 2021

Disetujui 30 Jan 2021

Terbit 28 Feb 2021

Kata Kunci

Estimasi, Produksi,

Klasifikasi, Naive Bayes Klasifikasi

\begin{abstract}
PT. Hasil Raya Industries is a company engaged in the manufacture of plastic goods such as bottles of packaging. During this time there is difficulty in calculating the estimated duration of the product work. Because the calculation of estimation is still manual, not well recorded and not accurate. To support the estimation of production time, a web-based system is designed to solve the problem. The authors apply the Naive Bayes algorithm based on Data Demand Goods and Production Data Data at PT. Hasil Raya Industries to give solution in finding time estimation at work of goods production This application can run well and can produce information as expected. By using the application time of production of goods, PT.Hasil Raya Industries can directly receive reports of estimation results of production time.
\end{abstract}

\begin{abstract}
Abstrak
PT. Hasil Raya Industries merupakan perusahaan yang bergerak pada bidang industri pembuatan barang plastik berupa botol kemasan. Selama ini terdapat kesulitan dalam melakukan perhitungan estimasi lama pengerjaan produk tersebut. Dikarenakan pada perhitungan estimasi masih manual, belum terdata dengan baik dan belum akurat. Untuk mendukung estimasi waktu produksi maka dirancang suatu sistem berbasis web yang dapat mengatasi masalah tersebut. Penulis menerapkan algoritma Naive Bayes berdasarkan Data Permintaan Barang dan Data Hasil Produksi pada PT. Hasil Raya Industries untuk meberikan solusi dalam mencari estimasi waktu pada pengerjaan produksi barang Aplikasi ini dapat berjalan dengan baik dan dapat menghasilkan informasi sesuai yang diharapkan. Dengan menggunakan aplikasi waktu pengerjaan produksi barang, PT.Hasil Raya Industries dapat langsung menerima laporan hasil estimasi waktu produksi.
\end{abstract}




\section{PENDAHULUAN}

Adanya kemajuan teknologi informasi ini menyebabkan pergeseran penggunaan teknologi dari tingkat sederhana menuju yang lebih modern. Dalam perusahaan terutama dibidang industri yang memerlukan informasi yang tepat dan akurat, sistem informasi ini sangat dibutuhkan dalam aktivitas perusahaan. Sehingga nantinya perusahaan dapat memasarkan dan menjual produknya dengan harga yang kompetitif dengan pesaingnya. Karena pada umumnya tujuan utama dari perusahaan adalah mencari keuntungan. Untuk mencapai tujuan tersebut, perusahaan harus menyusun rangkaian kegiatan, yang mana kegiatan tersebut harus selesai sesuai dengan waktu yang telah ditetapkan. Dengan adanya sistem informasi yang sesuai dengan sistem operasional perusahaan maka segala aktifitas didalam perusahaan tersebut akan dapat dilaksanakan dengan efektif dan efisien. Kemajuan atau keberhasilan suatu perusahaan salah satunya dipengaruhi oleh service kecepatan dalam pembuatan barang dari perusahan.

PT Hasil Raya Industries merupakan perusahaan manufaktur pembuatan botol kemasan. Dikarenakan banyaknya pemesanan botol dan para customer juga membutuhkan waktu estimasi untuk mengetahui barang yang mereka pesan. Hal ini sangatlah berkaitan dengan manajemen produksi. Maka dari itu penulis membuat sistem yang mampu menghitung estimasi waktu kapan selesainya produk tersebut, ini juga dapat mempermudah pihak manajemen produksi untuk pengambilan keputusan.

Dengan demikian berikut adanya data transaksi yang ada metode yang cocok digunakan yaitu dengan metode Naive Bayes. Naive Bayes adalah salah satu penerapan theorem Bayes dalam klasifikasi, Naive
Bayes didasarkan pada asumsi penyederhanaan bahwa nilai atribut secara konditional saling bebas jika diberikan nilai output. Klasifikasi Naive Bayes diasumsikan bahwa ada atau tidak ciri tertentu dari sebuah kelas tidak ada hubungannya dengan ciri kelas lainnya.

Untuk melihat dan mendapatkan estimasi waktu yang tepat, pihak perusahaan bisa mengamati dari transaksi penjualan dengan melakukan pengolahan terhadap data penjualan tersebut. Dengan proses pengolahan terhadap data penjualan ini, perusahaan bisa menghitung estimasi waktu yang dibutuhkan untuk menyelesaikan pesanan pelanggan, dengan tidak mengirangira kapan waktu penyelesaian tersebut.

Setelah melakukan pengidentifikasian masalah, maka ditentukan ruang lingkup masalah terhadap rancangan sistem ini, yaitu:

1. Pada penenelititian ini hanya membahas perhitungan estimasi waktu penyelesaian produksi tersebut.

2. Data yang di ambil dari PT. Hasil Raya Industries

3. Barang yang digunakan untuk sampel adalah botol Pet 20cc, botol HD 50ML RVM, botol HD 100gr MyBaby Polos, botol Jerigen HD 5 LT

Berdasarkan latar belakang dan identifikasi masalah diatas, maka permasalahan yang diajukan adalah:

1. Apakah metode Naive Bayes Klasifikasi dapat melakukan perhitungan estimasi waktu dengan tepat, serta bagaimana bentuk aplikasi untuk menentukannya ?

2. Berapa tingkat akurasi metode Naive Bayes Klasifikasi dalam mengkalasifikasikan estimasi waktu dalam pembuatan barang. 


\section{TINJAUAN PUSTAKA}

Pada penelitian yang berjudul "Penerapan Algoritma Naive Nayes Untuk Memprediksi Jumlah Produksi Barang berdasarkan Data Persediaan dan Jumlah Pemesanan Pada CV. Papadan Mama Pastries" Tujuan penelitian ini adalah memprediksi stock persediaan roti tawar kupas dan roti tawar gandum. Hasil dari penelitian ini, sistem bertugas menghitung nilai masing-masing dalam memprediksi persediaan stok roti, sehingga memperoleh hasil yang berupa data persediaan stok. Pada sistem ini akan menginput data-data persediaan stok berdasasrkan jenis roti tawar : roti tawar kupas, roti tawar gandum dan roti tawar coklat. [1]

Pada penelitian yang berjudul "Perbandingan Algoritma Klasifikasi Data Mining Model C4.5 Dan Naive Bayes Untuk Prediksi Penyakit Diabetes". Seiring dengan perkembangansistem berbasik komputer sebagai teknik analisa dalam mendiagnosa semakin penting. Oleh karena itu, penelitian ini dilakukan untuk membantu penyelesaian permasalahan tersebut dengan data mining yang berfungsi untuk memprediksi penyakit diabetes. [2]

Pada Penelitian yang berjudul "Model Forecasting Penjualan Sayuran Menggunakan Metode Naive Bayes". Ini menggunakan model forecasting dengan memanfaatkan data statistik penjualan yang ada dalam Jogja Organic, diolah dengan asumsi dapat meminimalisir adanya penumpukan stock sayuran dalam gudang penyimpanan. Hasil dari forecasting diharapkan mampu meningkatkan kinerja pegawai Jogja Organic dalam menentukan jumlah pemasokan sayuran, ketika berkurangnya pembelian sayuran oleh para konsumen. Sehingga tidak terjadi penumpukan sayuran pada gudang. [3]
Pada penelitian yang berjudul "Prediksi Data Buku Yang Sering Dipinjam Berdasarkan Kategori Pada Perpustakaan Daerah Demak Menggunakan Naive Bayes". Tujuan dari penelitian ini dalah menerapkan metode Naive Bayes untuk Memprediksi data buku yang sering dipinjam pada perpustakaan Daerah Demak karena sulitnya memprediksi data buku yang sering dipinjam. Hasil prediksi data buku yang sering dipinjam pada Perpustakaan Daerah Demak menggunakan metode Naive Bayes dapat memberikan hasil nilai prediksi untuk dijadikan sebagai prediksi bku tang sering dipinjam pada Perpustakaan Daerah Demak. [4]

Pada penelitian yang Berjudul "Implementasi Metode Klasifikasi Naive Bayes dalam Memprediksi Besarnya Pengunaan Listrik Rumah Tangga ". Begitu pentingnya peranan listrik tentu saja berdampak pada permintaan listrik yang semakin lama semakin besar,namun hal ini kiranya tidak linier dengan persediaan listrik yang belum mampu memenuhi permintaan listrik yang begitu besar. Dengan begitu pemerintah harus ikut campur tangan untuk mengatasi hal ini, agar listrik dapat digunakan dengan bijak. Sehingga kebutuhan listrik tidak menjadi lebih besar dari persediaan listrik. Penerapan metode Naive Bayes diharapkan mampu untuk memprediksi besarnya penggunaan listrik tiap rumah agar lebih mudah mengatur penggunaan listrik. [5]

\subsection{Pengertian Klasifikasi}

Klasifikasi adalah proses pengelompokan, artinya mengumpulkan benda/ entitas yang tidak sama. Secara umum dapat dikatakan bahwa batasan klasifikasi adalah usaha menata alam pengetahuan dalam tata urutas sistemasis. [6] 


\subsection{Pengertian Naive Bayes}

Algoritma Naive Bayes merupakan salah satu algoritma yang terdapat pada teknik klasifikasi. Naive Bayes merupakan pengklasidikasian dengan metode probalbilitas dan statik yang dikemukakan oleh ilmuwan inggris Thomas Bayes, yaitu memprediksi peluang di masa depan berdasarkan pengalaman dimasa sebelumnya sehingga dikenal sebagai Teorema Bayes. Teorema tersebut dikombinasikan dengan Naive dimana diasumsikan kondisi antar atribut independen. [7]

$$
P(H \mid X)=\frac{P(X \mid H) \cdot P(H)}{P(X)}
$$

Gambar 2. 1 Algoritma Naive Bayes

Dimana:

$X \quad$ : Data dengan class yang belum diketahui

$H \quad$ : Hipotesis data merupakan suatu class spesifik

$P(H \mid X)$ : Probabilitas hipotesis $\mathrm{H}$ berdasarkan kondisi $X$ (posteriori proba- bilitas)

$P(H) \quad$ : Probabiltas hipotesis $H$ (prior probabilitas)

$P(X \mid H)$ : Probabilitas berdasarkan kondisi pada hipotesis $\mathrm{H}$

$P(X) \quad$ : Probabilitas $X$

Adapun alur dari metode Naive Bayesadalah sebagai berikut :

a. Mulai

b. Baca data training

1. Hitung $\mathrm{P}(\mathrm{Ci})$ untuk setiap kelas
2. Hitung $P(X \mid C i)$ untuk setiap kriteria dan setiap kelas

3. Cari $\mathrm{P}(\mathrm{X} \mid \mathrm{Ci})$ yang paling besar menjadi kesimpulan

c. Tampilkan hasil prediksi.

\section{METODOLOGI PENELITIAN}

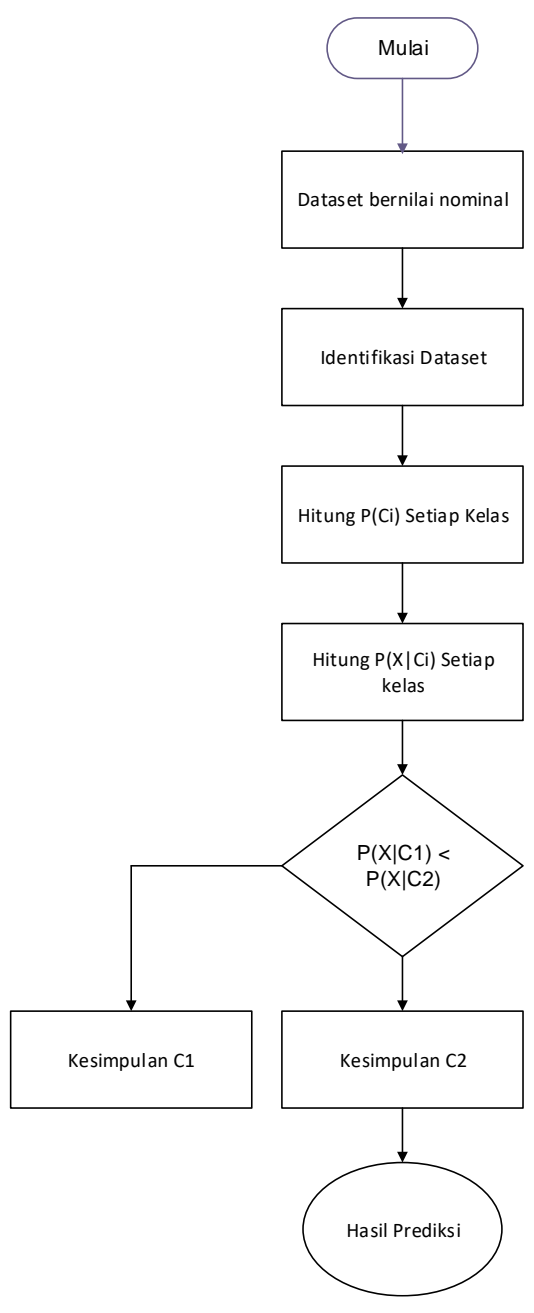

Penjelasan dari gambar di atas :

1. Baca data training

2. Perhitungan nilai likelihood

3. Normalisasi probabilitas

Mengambil keputusan sebuah data training masuk ke dalam class apa, perlu dilakukan normalisasi probabilitas.

4. Klasifikasi Waktu Estimasi 
Metode Naive Bayes Classifier digunakan untuk mengklasifikasi data berupa data atribut klasifikasi estimasi waktu berdasarkan jumlah pemesanan barang dan persediaan barang.

Pada proses klasifikasi dikenal dua jenis data yaitu data training dan data uji. Data training adalah data yang sudah ada sebelumnya berdasarkan fakta yang sudah terjadi. Sedangkan, data uji adalah data yang sudah berkelas/berlabel yang digunakan untuk menghitung akurasi model klasifikasi yang dibentuk

a. Persamaan dari teorema Bayes adalah :

$P(H \mid X)=\frac{P(X \mid H) \cdot P(H)}{P(X)}$

Keterangan :

X : Data Dengan class yang belum diketahui

$\mathrm{H} \quad$ : Hipotesis yang merupakan suatu class spesifik

$\mathrm{P}(\mathrm{X} \mid \mathrm{H})$ : Probabilistik hipotesis berdasarkan kondisi (posteoriori probability)

$\mathrm{P}(\mathrm{H}) \quad$ :Probabilitas hipotesis (prior probability)

$\mathrm{P}(\mathrm{X} \mid \mathrm{H})$ : Probabilitas berdaarkan kondisi pada hipotesis

$\mathrm{P}(\mathrm{X}) \quad$ : Probabilitas

Untuk menjelaskan teorema Naive Bayes perlu diketahui bahwa proses klasifikasi memerlukan sejumlah petunjuk untuk menentukan kelas apa yang cocok bagi sampel yang dianalisis tersebut. Karena itu, teorema bayes diatas disesuaikan sebagai berikut:

$$
P\left(C \mid F_{1 \ldots . . .} F_{n}\right)=\frac{P\left(C\left|F_{1 \ldots \ldots F_{n}}\right| C\right)}{P\left(F_{1} \ldots . . F_{n}\right)}
$$

Keterangan :

Variabel C : merepresentasikan kelas

Variabel F1...Fn : mempresentasikan karakteristik petunjuk yang dibutuhkan untuk melakukan klasifikasi.

\section{b. Perhitungan Nilai Likehood}

Maka rumus tersebut menjelaskan bahwa peluang masuknya sampel karakteristik tertentu dalam kelas C (Posterior) adalah peluang munculnya kelas C (sebelum masuknya sampel tersebut, seringkali disebut prior), dikali dengan peluang kemunculan karakteristik karakteristik sampel pada kelas C (disebut juga likehood), dibagi dengan peluang kemunculan karakteristik karakteristik sampel secara global (disebut juga evidence). Karena itu, rumus diatas dapat pula ditulis sederhana sebagai berikut :

Posterior $=\frac{\text { Prior } x \text { likelihood }}{\text { evidence }}$

Keterangan :

Posterior : perbaikan terhadap nilai probabilitas

Prior : nilai probabilitas awal

Likelihood :titik teertentu untuk memaksimalkan sebuah fungsi

Evidence : nilai bukti

c. Normalisasi Probabilitas

Nilai Evidence selalu tetap untuk setiap kelas pada satu sampel. Nilai dari posterior tersebut nantinya akan dibandingkan dengan nilai nilai posterior kelas lainnya untuk menentukan ke kelas apa suatu sampel akan diklasifikasikan. Penjabaran lebih lanjut rumus Bayes tersebut dilakukan dengan menjabarkan menggunakan aturan perkalian sebagai berikut : 


$$
\begin{aligned}
& P\left(C \mid F_{1 \ldots . . .} F_{n}=P(C) P\left(F_{1} \ldots \ldots F_{n} \mid C\right)\right. \\
& =P(C) P\left(F_{1} \mid C\right) P\left(F_{2} \ldots F_{n} \mid C, F_{1}\right) \\
& =\quad P(C) P\left(F_{1} \mid C\right) \quad P\left(F_{2} \mid C, F_{1}\right) \\
& \left(F_{1} \mid C\right) P\left(F_{3} \ldots F_{n} \mid C, F_{1}, F_{n-1}\right.
\end{aligned}
$$

Keterangan :

Variabel C : Merepresentasikan kelas variabel F1...Fn :Merepresentasikan karakteristik petunjuk yang dibutuhkan untuk melakukan klasifikasi.

\section{HASIL DAN PEMBAHASAN}

Berikut adalah hasil tampilan aplikasi yang sudah dibuat oleh penulis berbasis web :

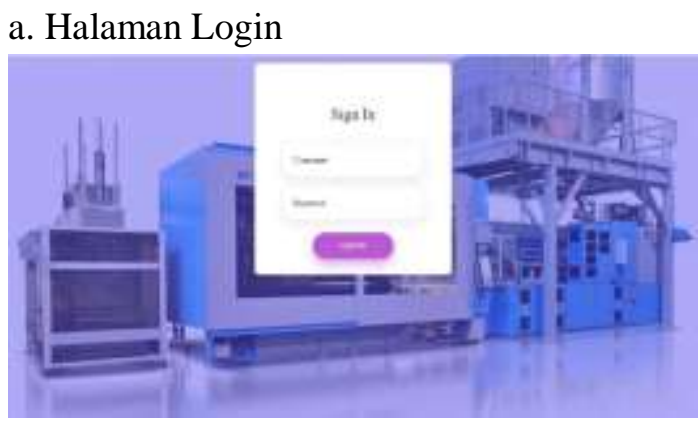

Gambar 1 Halaman Login

Diatas merupakan gambar dari form login Aplikasi estimasi waktu produksi untuk admin dan humas. Untuk dapat masuk kedalam sistem, maka pengguna harus melakukan login aplikasi dengan menggunakan username dan password dan mengklik tombol login. Terdapat dua hak akses terhadap aplikasi ini yaitu: admin dan user.

b. Halaman Beranda Aplikasi

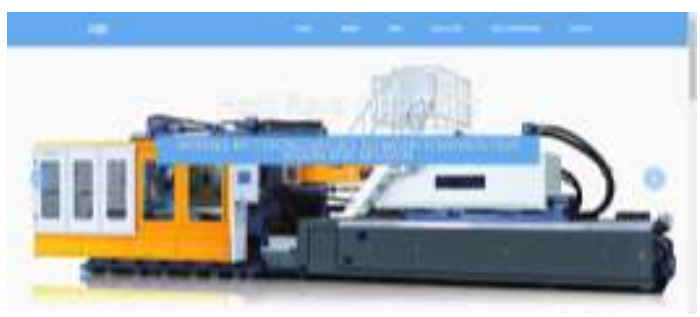

Gambar 2 Halaman Beranda Aplikasi
Diatas merupakan halaman beranda utama saat aplikasi dibuka atau dijalankan. Halaman beranda utama merupakan halaman pembuka aplikasi yang berisi slider gambar mesin pembuat botol.

\section{c. Halaman Data Pemesanan}

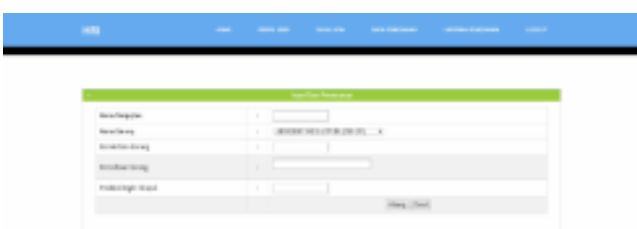

Gambar 3 Halaman Data Pemesanan

Gambar diatas merupakan halaman input data Pemesanan . Pada halaman Pemesanan ini user dapat menambahkan data pemesanan/ data yang akan diuji.

d. Rekapitulasi Hasil Perhitungan

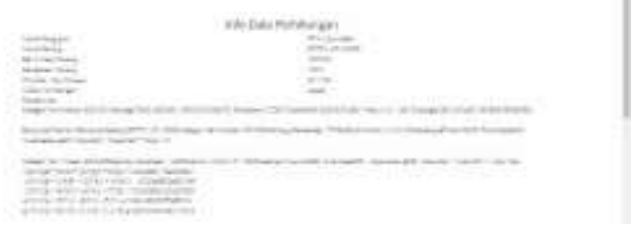

Gambar 4 Halaman Hasil Perhitungan

Gambar diatas merupakan halaman rekap pesanan. Pada halaman ini, seorang user dapat melihat perhitungan manual pada estimasi waktu produksi barang tersebut.

\subsection{Hasil Validasi Manual}

Berikut disajikan perhitungan manual berdasarkan analisa metode Naive Bayes dalam proses estimasi waktu produksi barang. Yang pertama melakukan pengambilan data training dari hasil produksi dan permintaan barang. Dari data tersebut terdapat beberapa variabel penentu yang 
digunakan dalam mengklasifikasikan data estimasi waktu. Dan berikut disajikan data training dan Data Uji.

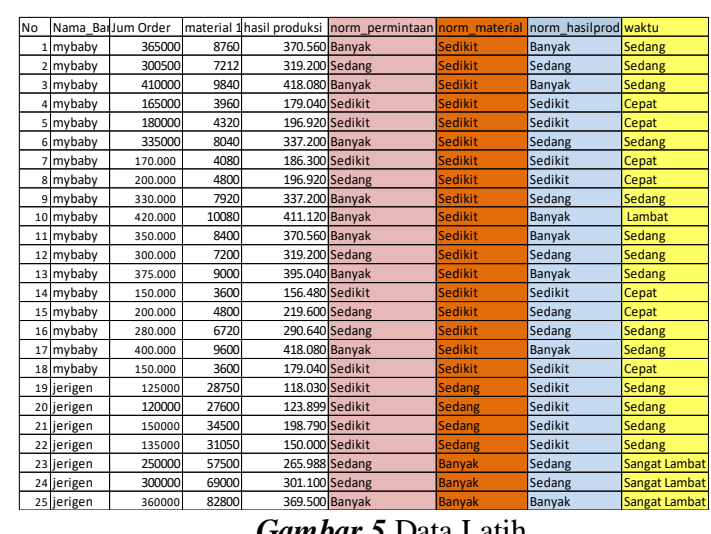

Gambar 5 Data Latih

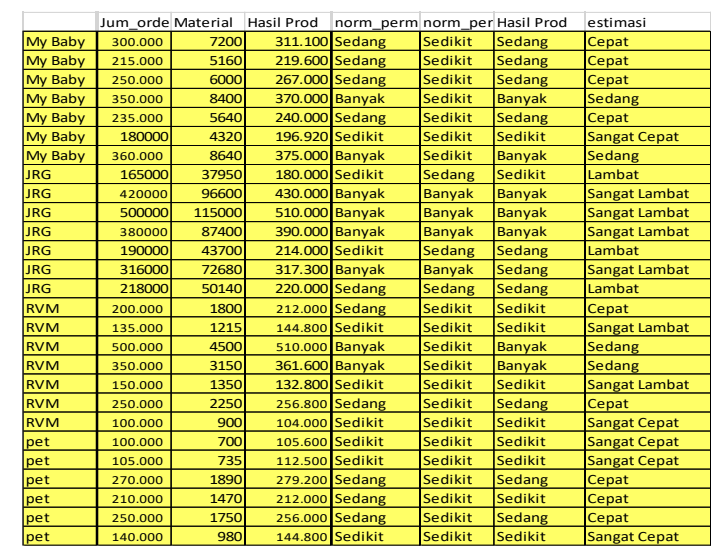

Gambar 6 Pengujuan Data Uji

a. Jumlah Order, merupakan variabel yang digunakan untuk mengetahui jumlah permintaan yang diinginkan oleh customer

b. Persediaan Barang, merupakan variabel yang digunakan untuk mengetagui jumlah material untuk membuat barang tersebut.

c. Hasil Prduksi, merupakan variabel yang digunakan untuk memasukkan jumlah barang yang akan diproduksi

d. Estimasi Waktu, merupakan variabel yang digunakan untuk mengetahui Hasil Estimasi tersebut.

\begin{tabular}{|l|l|l|}
\hline Kriteria & Kategori & Ket \\
\hline \multirow{4}{*}{$\begin{array}{c}\text { Waktu } \\
\text { Estimasi }\end{array}$} & Sangat Cepat & 10-16 Hari \\
\cline { 2 - 3 } & Cepat & 17-31 Hari \\
\cline { 2 - 3 } & Sedang & 33-49 Hari \\
\cline { 2 - 3 } & Lambat & 50-65 Hari \\
\cline { 2 - 3 } & Sangat Lambat & 66-80 Hari \\
\hline
\end{tabular}

\section{Normalisasi}

Pada normalisasi Permintaan, normalisasi persediaan, dan normalisasi Hasil Produksi diatas untuk mendapatkan klasifikasi yaitu dengan rumus seperti dibawah :

Range $=($ Max-Min $) / 3$

Range akan menjadi batas acuan yang digunakan untuk menormalisasikan. Klasifkasi dari range yang digunakan untuk menormalisasi adalah Sedikit, Sedang dan Banyak.

\section{Perhitungan Persamaan Likehood} $\mathrm{P}(\mathrm{C})$

Sangat Cepat $=26 / 109=29 / 124=0.23$

Cepat $=28 / 109=31 / 124=0.25$

Sedang $=23 / 109=26 / 124=0.21$

Lambat $=18 / 109=21 / 124=0.17$

Sangat Lambat $=14 / 109=17 / 124=$ 0.13

\section{Menghitung nilai kondisi probabilitas}

a. Jumlah Order

( $\mathrm{P}$ X=Sedikit $\mid \mathrm{C} 1=$ Sangat Cepat $)$

$=23 / 26=24 / 29$

( $\mathrm{P}$ X=Sedang $\mid \mathrm{C} 1=$ Sangat Cepat)

$=2 / 26=3 / 29$

( $\mathrm{P}$ X=Banyak $\mid \mathrm{C} 1=$ Sangat Cepat $)$

$=1 / 26=2 / 29$

$(\mathrm{P} X=$ Sedikit $\mid \mathrm{C} 2=$ Cepat $)=12 / 28=$ $13 / 31$

$(\mathrm{P} X=$ Sedang $\mid \mathrm{C} 2=\mathrm{C} \quad$ epat $)=12 / 28$ $=13 / 31$

( $\mathrm{P}$ X=Banyak $\mid \mathrm{C} 2=$ Cepat $)=4 / 28=$ $5 / 31$

$(\mathrm{P} X=$ Sedikit $\mid \mathrm{C} 3=$ Sedang $)=10 / 23=$ $11 / 26$

(P X=Sedang $\mid \mathrm{C} 3=$ Sedang $)=4 / 23$ $=5 / 26$

(P X=Banyak | C3= Sedang $)=9 / 23$ $=10 / 26$

$(\mathrm{P} X=$ Sedikit $\mid \mathrm{C} 4=$ Lambat $)=8 / 18=$ $9 / 21$

(P X=Sedang $\mid \mathrm{C} 4=$ Lambat $)=6 / 18$ $=7 / 21$ 
(P X=Banyak $\mid \mathrm{C} 4=$ Lambat $)=4 / 18=5 / 21$

(P X=Sedikit $\mid \mathrm{C} 5=$ Sangat Lambat $)=0 / 14=$ $1 / 17$

(P X=Sedang | C5=Sangat Lambat $)=7 / 14$ $=8 / 17$

$(\mathrm{P}$ X=Banyak | C5=Sangat Lambat $)=7 / 14$ $=8 / 17$

b. Persediaan

$(\mathrm{P} X=$ Sedikit $\mid \mathrm{C} 1=$ Sangat Cepat $)=26 / 26=$ 27/29

(P X=Sedang $\mid \mathrm{C} 1=$ Sangat Cepat $)=0 / 26=$ $1 / 29$

$(\mathrm{P}$ X=Banyak $\mid \mathrm{C} 1=$ Sangat Cepat $)=0 / 26=$ $1 / 29$

(P X=Sedikit $\mid \mathrm{C} 2=$ Cepat $)=26 / 28=27 / 31$

$(\mathrm{P} X=$ Sedang $\mid \mathrm{C} 2=$ Cepat $)=2 / 28=3 / 31$

$(\mathrm{P} X=$ Banyak $\mid \mathrm{C} 2=$ Cepat $)=0 / 28=1 / 31$

$(\mathrm{P} X=$ Sedikit $\mid \mathrm{C} 3=$ Sedang $)=15 / 23=16 / 31$

(P X=Sedang $\mid \mathrm{C} 3=$ Sedang $)=8 / 23=9 / 26$

$(\mathrm{P} X=$ Banyak $\mid \mathrm{C} 3=$ Sedang $)=0 / 23=1 / 26$

(P X=Sedikit $\mid \mathrm{C} 4=$ Lambat $)=4 / 18=5 / 21$

(P X=Sedang $\mid \mathrm{C} 4=$ Lambat $)=14 / 18=15 / 21$

$(\mathrm{P} X=$ Banyak $\mid \mathrm{C} 4=$ Lambat $)=0 / 18=1 / 21$

$(\mathrm{P} X=$ Sedikit $\mid \mathrm{C} 5=$ Sangat Lambat $)=0 / 14=$ $1 / 17$

(P X=Sedang $\mid \mathrm{C} 5=$ Sangat Lambat $)=0 / 14=$ $1 / 17$

(P X=Banyak | C5=Sangat Lambat) $=14 / 14$ $=15 / 17$

\section{c. Hasil Produksi}

$(\mathrm{P} X=$ Sedikit $\mid \mathrm{C} 1=$ Sangat Cepat $)=23 / 26=$ $24 / 29$

$(\mathrm{P} X=$ Sedang $\mid \mathrm{C} 1=$ Sangat Cepat $)=2 / 26=$ $3 / 29$

$(\mathrm{P}$ X=Banyak $\mid \mathrm{C} 1=$ Sangat Cepat $)=1 / 26$ $=2 / 29$

$(\mathrm{P} X=$ Sedikit $\mid \mathrm{C} 2=$ Cepat $)=13 / 28=$ $14 / 31$

(P X=Sedang $\mid \mathrm{C} 2=$ Cepat $)=9 / 28=$ $10 / 31$

(P X=Banyak $\mid \mathrm{C} 2=$ Cepat $)=6 / 28=$ $7 / 31$
(P X=Sedikit $\mid \mathrm{C} 3=$ Sedang $)=10 / 23$

$=11 / 26$

(P X=Sedang $\mid \mathrm{C} 3=$ Sedang $)=6 / 23$

$=7 / 26$

(P X=Banyak $\mid \mathrm{C} 3=$ Sedang $)=7 / 23$

$=8 / 26$

(P X=Sedikit $\mid \mathrm{C} 4=$ Lambat $)=8 / 18$ $=9 / 21$

(P X=Sedang $\mid \mathrm{C} 4=$ Lambat $)=6 / 18$

$=7 / 21$

(P X=Banyak $\mid \mathrm{C} 4=$ Lambat $)=4 / 18$

$=5 / 21$

(P X=Sedikit $\mid \mathrm{C} 5=$ Sangat Lambat)

$=0 / 14=1 / 17$

(P X=Sedang | C5=Sangat Lambat)

$=13 / 14=14 / 17$

(P X=Banyak | C5=Sangat Lambat)

$=1 / 14=2 / 17$

4. Menghitung nilai perkalian dari kondisi probabilitas

Jumlah Order

$(\mathrm{P} X=$ Sedikit $\mid \mathrm{C} 1=$ Sangat Cepat $)=$ 0.827

( $\mathrm{P}$ X=Sedang $\mid \mathrm{C} 1=$ Sangat Cepat)

$=0.103$

(P X=Banyak $\mid \mathrm{C} 1=$ Sangat Cepat)

$=0.068$

(P X=Sedikit $\mid \mathrm{C} 2=$ Cepat $)=0.419$

(P X=Sedang $\mid \mathrm{C} 2=$ Cepat $)=0.419$

(P X=Banyak $\mid \mathrm{C} 2=$ Cepat $)=0.161$

$(\mathrm{P} X=$ Sedikit $\mid \mathrm{C} 3=$ Sedang $)=0.423$

(P X=Sedang $\mid \mathrm{C} 3=$ Sedang $)=0.192$

$(\mathrm{P} X=$ Banyak $\mid \mathrm{C} 3=$ Sedang $)=0.384$

(P X=Sedikit $\mid \mathrm{C} 4=$ Lambat $)=0.428$

(P X=Sedang $\mid \mathrm{C} 4=$ Lambat $)=0.333$

(P X=Banyak $\mid \mathrm{C} 4=$ Lambat $)=0.238$

(P X=Sedikit $\mid \mathrm{C} 5=$ Sangat Lambat $)=0.058$

(P X=Sedang $\mid \mathrm{C} 5=$ Sangat Lambat $)=0.470$

P X=Banyak $\mid$ C5=Sangat Lambat $)=0.470$

a. Persediaan

$(\mathrm{P} X=$ Sedikit $\mid \mathrm{C} 1=$ Sangat Cepat $)=0.931$

$(\mathrm{P} X=$ Sedang $\mid \mathrm{C} 1=$ Sangat Cepat $)=0.034$ 
(P X=Banyak $\mid \mathrm{C} 1=$ Sangat Cepat $)=0.034$

(P X=Sedikit $\mid \mathrm{C} 2=$ Cepat $)=0.870$

(P X=Sedang $\mid \mathrm{C} 2=$ Cepat $)=0.096$

(P X=Banyak $\mid \mathrm{C} 2=$ Cepat $)=0.032$

$(\mathrm{P} X=$ Sedikit $\mid \mathrm{C} 3=$ Sedang $)=0.615$

(P X=Sedang $\mid \mathrm{C} 3=$ Sedang $)=0.346$

$(\mathrm{P} \mathrm{X}=$ Banyak $\mid \mathrm{C} 3=$ Sedang $)=0.038$

(P X=Sedikit $\mid \mathrm{C} 4=$ Lambat $)=0.238$

(P X=Sedang $\mid \mathrm{C} 4=$ Lambat $)=0.714$

(P X=Banyak $\mid \mathrm{C} 4=$ Lambat $)=0.047$

(P X=Sedikit $\mid \mathrm{C} 5=$ Sangat Lambat $)=0.058$

$(\mathrm{P} X=$ Sedang $\mid \mathrm{C} 5=$ Sangat Lambat $)=0.058$

$(\mathrm{P} X=$ Banyak $\mid \mathrm{C} 5=$ Sangat Lambat $)=0.882$

c. Hasil Produksi

(P X=Sedikit $\mid \mathrm{C} 1=$ Sangat Cepat $)=0.827$

(P X=Sedang $\mid \mathrm{C} 1=$ Sangat $\mathrm{Cepat})=0.103$

$(\mathrm{P} X=$ Banyak $\mid \mathrm{C} 1=$ Sangat $\mathrm{Cepat})=0.068$

(P X=Sedikit $\mid \mathrm{C} 2=$ Cepat $)=0.722$

(P X=Sedang $\mid \mathrm{C} 2=$ Cepat $)=0.322$

(P X=Banyak $\mid \mathrm{C} 2=$ Cepat $)=0.225$

$(\mathrm{P} X=$ Sedikit $\mid \mathrm{C} 3=$ Sedang $)=0.432$

(P X=Sedang $\mid \mathrm{C} 3=$ Sedang $)=0.269$

(P X=Banyak $\mid \mathrm{C} 3=$ Sedang $)=0.307$

(P X=Sedikit $\mid \mathrm{C} 4=$ Lambat $)=0.428$

$(\mathrm{P} X=$ Sedang $\mid \mathrm{C} 4=$ Lambat $)=0.333$

(P X=Banyak $\mid \mathrm{C} 4=$ Lambat $)=0.238$

(P X=Sedikit $\mid \mathrm{C} 5=$ Sangat Lambat $)=0.058$

(P X=Sedang $\mid \mathrm{C} 5=$ Sangat Lambat $)=0.823$

$(\mathrm{P} X=$ Banyak $\mid \mathrm{C} 5=$ Sangat Lambat $)=0.117$

5. Menghitung nilai klasifikasi

\begin{tabular}{|c|c|l|c|}
\hline NO & $\begin{array}{c}\text { Permintaa } \\
\mathrm{n}\end{array}$ & Persediaan & $\begin{array}{c}\text { Produksi } \\
\text { yg ini } \\
\text { dicapai }\end{array}$ \\
\hline 2 & 300000 & 7200 & 311100 \\
\hline
\end{tabular}

\begin{tabular}{|c|c|c|c|c|}
\hline NO & $\begin{array}{c}\text { Norm_- } \\
\text { Permin } \\
\text { taan }\end{array}$ & $\begin{array}{c}\text { Norm_ } \\
\text { Persedi } \\
\text { aan }\end{array}$ & $\begin{array}{c}\text { Norm_ } \\
\text { Produk } \\
\text { si }\end{array}$ & $\begin{array}{c}\text { Waktu } \\
\text { Estimasi }\end{array}$ \\
\hline 2 & Sedang & Sedikit & Sedang & $?$ \\
\hline
\end{tabular}

Normalisasi Permintaan : $30000=$ Sedang (8000-430000: 116666.66666667 => Range)
Normalisasi Persediaan :

$7200=$ Sedikit $(360-82800: 27480$

$\Rightarrow$ Range)

Normalisasi Produksi

$311100=$ Sedang $(82800-474400$ :

130533.33333333 => Range )

$\underline{\text { Sangat Cepat }} * \underline{P(\text { Persediaan }=\text { Sedang }} *$ Total Sangat Cepat $\frac{P(\text { Persediaan }=\text { Sedikit }}{\text { Sangat Cepat }} *$

$\frac{P(\text { Produksi }=\text { Sedang }}{\text { Sangat Cepat }}=\frac{29}{124} * \frac{3}{29} * \frac{27}{29} *$

$\frac{3}{29}$

$=0,233 * 0,103 * 0,931 * 0,103$

$=0,0023$

$\frac{\text { Cepat }}{\text { Total }} * \frac{P(\text { Persediaan }=\text { Sedang }}{\text { Sangat Cepat }} *$

$\underline{P(\text { Persediaan }=\text { Sedikit }} *$

Sangat Cepat

$\frac{P(\text { Produksi=Sedang }}{\text { Sangat Cepat }}=\frac{31}{124} * \frac{13}{31} * \frac{27}{31} *$

$\frac{10}{31}$

$=0,25 * 0,419 * 0,870 * 0,322$

$=0,0292$

$\frac{\text { Sedang }}{\text { Total }} * \frac{P(\text { Persediaan }=\text { Sedang }}{\text { Sangat Cepat }} *$

$\underline{P(\text { Persediaan }=\text { Sedikit }} *$

Sangat Cepat

$\frac{P(\text { Produksi }=\text { Sedang }}{\text { Sangat Cepat }}=\frac{26}{124} * \frac{5}{26} * \frac{16}{26} *$

$\frac{7}{26}$

$=0,21 * 0,192 * 0,615 * 0,269$

$=0,0073$

$\frac{\text { Lambat }}{\text { Total }} * \frac{P(\text { Persediaan }=\text { Sedang }}{\text { Sangat Cepat }} *$

$\underline{P(\text { Persediaan }=\text { Sedikit }} *$ Sangat Cepat

$\frac{P(\text { Produksi }=\text { Sedang }}{\text { Sangat Cepat }}=\frac{21}{124} * \frac{7}{21} * \frac{5}{21} *$

$\frac{7}{21}$

$=0,17 * 0,333 * 0,238 * 0,333$

$=0,004$ 
$\frac{\text { Sangat Lambat }}{\text { Total }} * \frac{P(\text { Persediaan }=\text { Sedang }}{\text { Sangat Cepat }} *$ $\underline{P(\text { Persediaan }=\text { Sedikit }} * \underline{P(\text { Produksi }=\text { Sedang }}$

$$
\begin{aligned}
& =\frac{17}{124} * \frac{8}{17} * \frac{1}{17} * \frac{14}{17} \\
& =0,11 * 0,470 * 0,058 * 0,823 \\
& =0,0024
\end{aligned}
$$

Karena nilai "Cepat" paling tinggi dibanding dengan lainnya, maka pada produksi tersebut estimasi waktu nya Cepat.

\section{KESIMPULAN}

Dari hasil kesimpulan yang dilakukan mulai tahap awal hingga proses pengujian Aplikasi Estimasi Waktu Produksi dengan menggunakan Algoritma Naive Bayes pada PT. Hasil Raya Industries dapat disimpulkan bahwa :

1. Dengan menerapkan metode Naive Bayes dapat memudahkan untuk menentukan estimasi waktu pengerjaan suatu barang. Dengan output hasil estimasi Cepat, Sangat Cepat, Sedang, Lambat, sangat Lambat.

2. Tingkat akurasi kinerja sistem dalam pengklasifikasian estimasi waktu pada produksi barang adalah 92,30\%. Lebih banyak terdapat data yang kontinu dibandingkan dengan data diskrit, dalam hal inilah yang mempengaruhi perhitungan pada kinerja sistem yang digunakan.

\section{DAFTAR PUSTAKA}

Manalu, E., Sianturi, F. A., \& Manalu, M. R. (2017). Penerapan Algoritma Naive Bayes Untuk Memprediksi Jumlah Produksi Barang Berdasarkan Data Persediaan dan Jumlah Pemesanan Pada CV. Papadan Mama Pastries. 1 No 2 Desember 2017.

Fatmawati. (2016). Perbandingan Algoritma Klasifikasi Data Mining Model C4.5 dan Naivr Bayes untuk Prediksi
Penyakit DIabetes. XIII, No. 1 Maret 2016.

Oktafiani, L., \& Purnomo, H. D. (2016). Model Forecasting Penjualan Sayuran Menggunakan Metode Naive Bayes (Studi Kasus: Jogja Organic, Yogyakarta).

Serovia, L., \& Sudaryanto, S. (2016). Prediksi Data Buku yang Sering Dipinjam Berdasarkan Kategori Pada Perpustakaan Daerah Dmak Menggunakan Metode Naive Bayes

Saleh, A. (2015). Implementasi Metode Klasifikasi Naive Bayes Dalam Memprediksi Besarnya Penggunaan Listrik Rumah Tangga. Citec Journal.

Basuki, S. (1991). Pengantar Ilmu Perpustakaan. Jakarta: PT Gramedia Pustaka Utama.

Prasetyo, E. (2012). Data Mining-Konsep dan Aplikasi menggunakan MATLAB. Yogyakarta: Andi. 